\title{
Peter of Candia's Hundred-Year "History" of the Theologian's Role
}

\author{
STEPHEN F. BROWN
}

Pitros Philargis (Petrus Philaretus) was born of Greek parents on the island of Crete (Candia) around 1340. Left an orphan at an early age, he was cared for by Italian Franciscans. After joining the Franciscan order on Crete in 1357, he was sent to Padua for his studies in the Arts. He attended the Franciscan studium generale at Norwich and also that at Oxford, where he received his baccalaureate in theology. From 1378-1380, he lectured ordinarie on the Sentences at Paris, obtaining his doctorate in theology in the fall of 1381. Quite likely he became a lecturer in Lombardy, for we know he was lecturing on theology at the convent of St. Francis in Pavia during the school year of 1384-1385.

Ioannes Galeatus, the duke of Milan, saw great promise in Peter's oratorical and administrative abilities and made him one of his counselors. His talents were also noted by Pope Urban VI, who named him bishop of Placenza in 1386. Early in 1388 Peter became bishop of Vicenza; a year later, of Novara; and within three years, of Milan, where he became cardinal in 1405 .

These episcopal offices did not interfere with his temporal duties in the service of Ioannes Galeatus. Peter was the prime minister to 
Galeatus and his son for more than a decade. He was also a "Father of letters" in the literary circle of the duke of Pavia from the time he arrived to teach there. He was a close friend of Hubertus Decembris, the leading representative of humanism in Lombardy, and of Antonius Lusco, the learned humanist who was chancellor to the duke of Milan. Peter's sermons and poems show a man deeply learned in humanistic sources, a man of lofty literary style. His collationes, or principal sermons, presented as introductions to each of his commentaries on the four books of Lombard's Sentences, reveal a striking literary power and a vast knowledge of patristic sources. His commentaries on the Sentences offer a clear academic style and show him to be a well-balanced scholar rather than a deep, creative thinker.

During the last half of Peter's life, the Christian world was in great disarray. In 1278, Clement VII claimed for himself the papal authority held legitimately, but not clearly, by Urban VI. The great schism that ensued in the Western religious world led over the years to a growing number of advocates of conciliarism. Along with many other cardinals, Peter saw a general council as the solution to this ecclesiastical conflict. On 25 March 1409, a general council was called at Pisa with the hope of putting an end to the schism. The council, after many stormy sessions, declared both popes deposed, and in the nineteenth session it elected Peter as pope. Taking the name of Alexander V, Peter did not settle the papal conflict. In fact, his election only confused things more, by increasing the number of popes to three. He set up his residence at Bologna in January 1410 but died there, in the convent of St. Francis, on 3 May of the same year. ${ }^{1}$

r. For the best general introductions to the life and works of Peter of Candia, see F. Ehrle, Die Sentenzenkommentar Peters von Candia, Franziskanische Studien 9 (Münster in Westf.: Aschendorff, 1925); as well as L. Salembier, "Alexandre V," DTC 1 (1923), cols. 722-724; and A. Emmen, "Petrus de Candia, O.F.M. De immaculata Deiparae conceptione," in Tractatus quatuor de immaculata conceptione B. Mariae Virginis, Bibliotheca Franciscana Scholastica 16 (Quaracchi: Collegium S. Bonaventurae, 1954), pp. 235-259. The only parts of his Sentences-commentary edited so far are the convocation sermons that he delivered each term on the four books of Lombard and the De immaculata Deiparae conceptione (an excerpt from book 3 of the Sentences). See S. F. Brown, "Peter of Candia's Sermons in Praise of Peter Lombard," in Studies Honoring Ignatius Charles Brady, Friar Minor, Franciscan Institute Publications, theology series 6 (St. Bonaventure, N.Y., 1976), pp. 141-176; and Emmen, "Petrus de Candia." 
As we have mentioned, Peter of Candia delivered his lectures on Lombard's Sentences at Paris over the two-year period 1378-1380. He opened the prologue to his Commentary on book I, where theology teachers usually asked what kind of habit or developed ability is fostered by study in the theology faculty, with the question: "Does the intellect of human beings here in this world acquire through theological study evident knowledge of revealed truths?"2

In formulating his response Peter provided a brief introduction to the positions of the great thirteenth- and fourteenth-century thinkers who influenced him both negatively and positively: Thomas Aquinas, John of Naples, Peter Aureoli, John Duns Scotus, William of Ockham, and Gregory of Rimini.

\section{AQUINAS'S POSITION}

Peter of Candia notes only two things concerning Aquinas's position: Thomas held that the ability developed by theological study is science in the proper Aristotelian sense of the term; and, more specifically, that theological study has the character of a subaltern science. ${ }^{3}$ Interpretations of what exactly the Angelic Doctor was trying to say in the first question of his Summa theologiae provoke divisions not only among his modern-day interpreters or such famed commentators as Cajetan and John of St. Thomas but also among his contemporaries in the schools of theology. ${ }^{4}$

Following the detailed critique of Godfrey of Fontaines, the four-

2. Peter of Candia Sent. 1.pro (lines 6-8). The edition is given below, in the appendix.

3. Peter of Candia Sent. 1.pro. 1 (lines 163-164, 188-189, 197-198, 444-445). Cf. Thomas Aquinas Summa theol. 1.1.2.

4. For the interpretations of the classical commentators, see the references given by J. A. Weisheipl, "The Meaning of Sacra Doctrina in Summa theologiae I, q. 1," The Thomist 28 (1974): 56-60, where he presents the views of Cajetan, Bañez, Sylvius, John of St. Thomas, Billuart, Buonpensiere, and Garrigou-Lagrange. For the more recent understandings of Thomas, some starting points would be J. Beumer, "Thomas von Aquin zum Wesen der Theologie," Scholastik 32 (1955): 195-214; J. F. Bonnefoy, "La théologie comme science et l'explication de la foi selon saint Thomas d'Aquin," in Ephemerides Theologicae Lovanienses 14 (1937): 421-446, 600-631, and 15 (1938): 491-516; M. D. Chenu, La théologie comme science au XIIle siècle (Paris: J. Vrin, 1957); M. Grabmann, "Il concetto di scienza secondo s. Tommaso d'Aquino e le relazioni della fede e della teologia con la filosofia et le scienze profane," Rivista filosofia neoscolastica 26 (1934): 127-155; G. F. Van Ackeren, Sacra Doctrina: The 
teenth-century theologians Scotus, Aureoli, Ockham, and Rimini took Aquinas to mean what he said in the passage in its proper and strict sense. ${ }^{5}$ Godfrey, for example, in his Quodlibet 4 of 1287 , represents Thomas as holding that the theologian, while proceeding from principles that are held by divine faith, arrives at conclusions concerning which he truly has science. ${ }^{6}$ The plausibility of such a position is founded on the parallel that Aquinas saw between Aristotle's view of the relation of a subalternating and subaltern science and the case of theology. Just as a subaltern science, such as optics, borrows principles from a subalternating science, such as geometry, and still is a true, if subaltern, science, so theology borrows its principles from the knowledge that God and the blessed in heaven have of the divine mysteries. Using such truths as premises, theology arrives at conclusions that are true, though subaltern, science. ${ }^{7}$

Godfrey, however, accepted neither the logic of the main argument nor the simile. For him science carries a twofold certitude: the certitude of evidence and the certitude of adherence, i.e., holding to the truth of something without any doubt. Faith has the latter type of certitude, but not the certitude of evidence. Faith, then, resembles knowledge to the extent that it has certainty but differs from knowledge because it lacks the certitude of evidence. Faith also is like opinion insofar as both faith and opinion lack the certitude given by evidence; but faith differs from opinion since it has the certitude of adherence, which opinion lacks.

Subject of the First Question of the Summa Theologica of St. Thomas Aquinas (Rome: Catholic Book Agency, 1952); and the article of Weisheipl mentioned above. C. Dumont provides helpful leads to early attemps to interpret Thomas in a more favorable light than Godfrey of Fontaines in his article "La réflexion sur la méthode théologique (II)," Nouvelle revue théologique 84 (1962): 26-32.

5. Scotus Sent. 3.24.1.2-3 (ed. Vivès, 15:36-37); William Ockham Scriptum in I Sent. pro. 7 (ed. G. Gál and S. F. Brown, 184); Peter Aureoli Scriptum 1.pro.1.2-8 (ed. E. M. Buytaert, 1:132-133); Gregory of Rimini Sent. 1.pro.1.3 (ed. Venice, 1521, a6vL-Q).

6. Godfrey of Fontaines Quodl. 4.10 (ed. M. DeWulf and J. Hoffmans, Les philosophes belges 2:261). Cf. P. Tihon, Foi et théologie selon Godefroid de Fontaines (Paris and Bruges: Desclée De Brouwer, 1966), pp. 120-131. Henry of Ghent likewise criticizes the subalternation theory of Aquinas in his Summa quaestionum ordinariarum 7.5 (Paris, 1520, ff. 53r-54v).

7. Thomas Aquinas Summa theol. 1.1.2. 
Basing his argument on the foundation of these distinctions, Godfrey argued:

Therefore, to say that the principles of theology or of any science whatsoever within theology are only believed and not known or understood, and thus while only having the certitude of adherence that they produce the certitude of science in the conclusions drawn from them, is to say that conclusions are better known than the principles, namely, that the conclusions have both types of certitude whereas the principles have only the one. Now this is to say contradictory things, and it harms on a large scale theology and its teachers to propose such fictitious claims concerning it to those entering upon its study. 8

Neither is the simile that is introduced into the argument worthwhile, because no one with a balanced mind understands that subaltern science is truly science if it only has opinion about its principles, for it gets them from a higher science and awards to them purely human faith due to the fact that they are known and handed down by an expert in a higher science. For whatever is drawn from principles that are handed down or held on faith-since they could not have certitude unless they went back and established it in those principles-would only be believed or accepted as opinion. Whatever is drawn from such principles might even be weaker than the principles themselves. So, then, is it the case with theology: although the principles of theology may be most certain in themselves and evident to God and the blessed, yet insofar as they are revealed by God, they are believed. Just as human authority begets opinion, a state of mind lacking both types of certitude, so divine authority produces faith, a state of mind having the certitude of adhering without fear of error. Of what advantage is it for a person using such principles accepted on authority and only believed by him and deriving conclusions from them, that the blessed have the certitude of evidence in regard to the principles and that the principles in themselves are evident and certain? The certitude of the blessed does not bring him evidence. Therefore, it is necessary that the principles of subaltern science be certain with the certitude of evidence in order that one may have science of the conclusion derived from them. ${ }^{9}$

8. Godfrey of Fontaines Quodl. 4.10 (ed. DeWulf and Hoffmans, Les philosophes belges, 2:261).

9. Godfrey Quodl. 4.10 (262). 
Early reaction to Godfrey's presentation of the subaltern approach to theology gave rise to a different reading of Thomas's text by James of Metz, ${ }^{10}$ Hervaeus Natalis, ${ }^{11}$ and Bernard of Auvergne. ${ }^{12}$ By the time we come to Duns Scotus, the arguments defending the subaltern science position are not strictly speaking Thomas's but those of these followers. ${ }^{13}$ In Peter Aureoli's Scriptum, the supports for Aquinas's theory are sevenfold and subtle, but Aureoli admits frankly that they may not really represent Thomas's own position ("quamvis non ponantur ab eis"). ${ }^{14}$ In fact they come from Godfrey and Scotus, at least in their direct formulation, though in turn they may well represent earlier attempts to clarify Thomas's position itself. ${ }^{15}$ When we come to our author, Peter of Candia, any real historical connection with Aquinas is gone. Candia gives Aquinas's name, but the position is not meant to be a historical portrait of the Angelic Doctor's theory. Thomas's position represents the limit position of evidence: the study of theology never brings the student to such evidence that he in this life has the certitude of evidence for his conclusions. To expect such is to ask too much of theology. 16

\section{THE THEOLOGY OF CONSEQUENCES}

If there is an outer limit of expectation for Candia, so is there an inner limit of expectation-when one allows no evidence at all in regard to the contents of theological discussion and reduces theology to a knowledge of consequences. In this view the theologian is considered a believer who has the ability to lead theological conclusions back to the basic principles or truths of faith. Already in the

10. Cf. C. Dumont, "La réflexion," p. 26, n. 64.

I I. See E. Krebs, Theologie und Wissenschaft nach der Lehre der Hochscholastik an der Hand der bisher ungedruckten Defensa doctrinae D. Thomae des Hervaeus Natalis, BGPM 11/3-4 (Münster, 1912), p. 37*.

12. See P. Stella, "Teologi e teologia nelle 'Reprobationes' di Bernardo d'Auvergne ai Quodlibeti di Goffredo di Fontaines," Salesianum 19 (1957): 187-189.

13. Scotus Sent. 3.24.1.2-3 (ed. Vivès, 15:36-37).

14. Aureoli Scriptum 1.pro.1.1.23 (ed. Buytaert, 1:139). For the arguments themselves, see nos. 2-8 (1:132-133).

15. See S. R. Streuer, Die theologische Einleitungslehre des Petrus Aureoli (Werl in Westf.: Dietrich-Coelde Verlag, 1968), pp. 64-65.

I6. Peter of Candia Sent. 1.pro. 1 (lines 162-166). 
1230s Odo Rigaud defended a place for theology among the sciences, defined according to the new Aristotelian ideal, by showing that sacred science uses scientific procedures. The theologian truly arrives at conclusiones causaliter demonstratae, since he follows the demonstrative process of Aristotelian science. ${ }^{17}$

Though theology may imitate the Aristotelian method of argumentation, still the perception of consequences is not, in Godfrey of Fontaines's eyes, for example, a sufficient definition of the goal of theological study. ${ }^{18}$ "This is to attribute too little to the theologian's task." Theological study should also deepen our knowledge of the mysteries of our faith. ${ }^{19}$

In truth, and despite the rhetoric of their opponents, neither Odo Rigaud nor John of Naples-to whom the position is also often attributed-nor any other theologian held that the sole goal of theological study was the perception of consequences. ${ }^{20}$ Logical ability plays an important role in theological study, but it is not the only, nor even the most important, role. By the time we come to Peter of Candia, however, the intensity of earlier debate concerning the theology of consequences is gone. For him this is, once again, a limit position. That is why he represents it in its absolute and exclusive form: "others have said that theology is only a knowledge of consequences." 21

\section{THE POSITION OF PETER AUREOLI}

Candia's format so far reveals not only the framework of his own treatment, but also the cadres of many fourteenth-century conceptions of theology. Theological study never attains evidence the way a strict Aristotelian science does-that would claim so much evidence that it would take away faith. Nor is it limited to the study of formal logical relationships between theological principles and conclusions drawn from them-that gives no evidence at all to truths of

I 7. C. Dumont, "La réflexion," pp. 20-22.

18. Godfrey of Fontaines Quodl. 9.20 (ed. DeWulf and Hoffmans, 4:285).

19. Ibid.

20. Cf. R. Guelluy, Philosophie et théologie chez Guillaume d'Ockham (Louvain and Paris: E. Nauwelaerts-J. Vrin, 1947), p. 55, n. 1.

21. Peter of Candia Sent. 1.pro.1 (lines 191-192). 
the faith but shows at best only a logical acumen regarding the interconnection of theological truths. These dimensions are the general limits within which Peter of Candia asks the question: "Does the intellect of human beings here in this world acquire through theological study evident knowledge of revealed truths?" In formulating his response within the framework just described, his theological companions now are Scotus, Aureoli, Ockham, and Rimini.

Within the borders of these two limit positions, Candia presented two approaches to theology with which he disagreed on certain points. They were the declarative theology of the French Franciscan Peter Aureoli, who commented on the Sentences at Paris in 1316-1318,22 and the deductive theology of the Augustinian hermit Gregory of Rimini, who began his Sentences-commentary, also at Paris, in 1343.23

Aureoli realized that many different types of intellectual activities legitimately go on in theology and that one could not reasonably limit the study to what is properly theological discourse. ${ }^{24}$ Sometimes, for example, theologians are no different from metaphysicians. When they argue for the unicity or infinity of God, they do so demonstratively from necessary and naturally known propositions that could force the intellectual assent of a pagan or a philosopher. When theologians argue in this way frequently, they develop a certain intellectual facility. Yet such a habit is metaphysical rather than properly theological. 25

At other times theologians are quite different from metaphysicians. They argue from premises that have their origin and ground in faith. In arguing correctly from premises rooted in revelation, they can produce conclusions that are not evident in the way metaphysical conclusions are, but that are nonetheless certain, provided the argument

22. Aureoli Scriptum I, intro. by E. M. Buytaert (1:xv). For the latest appreciation of Aureoli, see K. H. Tachau, Vision and Certitude in the Age of Ockham (Leiden and New York: E. J. Brill, 1988).

23. O. Grassi, "La questione della teologia come scienza in Gregorio da Rimini," Rivista di filosofia neoscolastica 68/1 (1976): 610, n. 1.

24. Aureoli Scriptum 1.pro.1 (ed. Buytaert, 1:132-175). Aureoli's position on the nature of theology is explained in detail by Streuer, Einleitungslehre, pp. 20-78. For Candia's summary, see Peter of Candia Sent. 1.pro. 1 (lines 91-115).

25. Aureoli Scriptum 1.1.2.77-79 (ed. Buytaert, 1:154-155; hereafter, citations of Aureoli Scriptum 1 shorten the parenthetical reference to the first volume of Buytaert's edition to page numbers only). 
consists of two revealed premises or one revealed and one necessary premise. An example of the latter type could be: (1) In Christ there are two intellectual natures, a divine one and a human one. (2) Now every intellectual nature has its own will. (3) Therefore, in Christ there are two wills, a divine one and a human one. Such a conclusion is held by faith, and Aureoli asserted that by arguments of this kind one does not acquire any habit distinct from faith. One holds to the conclusion by faith unhesitatingly, not because of the deduction per se, but because one believes the faith-premise from which the conclusion is inferred by necessity. What takes place here is a specification or a making explicit of faith. ${ }^{26}$

Sometimes, furthermore, theologians may begin with premises that are premises of faith and join to them in their arguments premises that are probable. The result is a conclusion that is opinion. The same result occurs if they work completely with unrevealed, probable premises of natural reason. In many questions within theological treatises, this procedure is the type of argument in play. It provides us with the opinions of theologians. 27

Godfrey of Fontaines, we might recall, distinguished three types of knowledge: science (having both the certitude of evidence and the certitude of adherence); faith (having only the certitude of adherence); and opinion (having neither certitude). In his critique of Thomas he focused on the knowledge of conclusions. Aureoli continues to this point along the same line: he analyzes the different types of arguments and the premises involved and gives the knowledgevalue of the conclusions in terms of the weight of their varying premises. Some of the arguments in theology do give us conclusions that are truly scientific. Others present conclusions lacking the certitude of evidence but possessing the certitude of conviction. Finally, many others offer conclusions that are plainly the opinions of theologians. Granting the precision of such detailed analysis of the knowledgevalue of various conclusions, and realizing that a great deal of effort in theology is given to such deductive activity, Aureoli thought that he had not yet come to what theology is properly about. In carrying out their proper role, theologians do not focus on conclusions drawn from articles of faith. Rather, they center themselves on what such deduc- 
tive theology would call premises or principles, certain revealed propositions whose truth has been determined by the Church-namely, the articles of faith. They do not start with them as principles and unfold new conclusions of varying worth depending on the other premises they use; rather, they focus on these very articles of faith and attempt to bring clarity to them (declarare eas). ${ }^{28}$ For Aureoli, this is the discipline of the theologian that is most properly theological. It is not science, since theologians do not demonstrate such truths. Neither is it faith, since they already believe them. Nor is it opinion, since they bring forth arguments from other sciences that give support for the articles of faith, or explain the meaning of the terms of these articles, or respond to doubts raised against them. All of this is not opinion, for such operations do not bring with them any hesitancy regarding the truths of faith. Indeed, it would be foolish to spend so much effort in explaining, supporting, and defending the articles of faith if the end result were to weaken one's faith by reducing it to hesitant opinion. In developing such skills of support, clarification, and defense, the theologian does not produce conviction such that he can now affirm these truths without fear of error. He was already convinced through faith. Rather, he develops a habit distinct from faith-allowing him to make more clear what he already unhesitatingly believed. It was this type of developed ability that the quaestiones of the theologians, the Books of the Sentences, the writings of the Fathers, and the readings and expositions of Scripture were intended to foster. A theologian in the proper sense of the term, in contrast to the ordinary believer, is said to understand to some degree what he believes and is "ready to give an account concerning those things which are in him by faith." 29 He knows how "to defend the faith against the impious and strengthen it in the minds of the pious." 30

Surely such a declarative theology carries on argumentation to support or illumine in some way the articles of faith. It borrows from other sciences premises of all different weights and employs them to support or illustrate as well as possible the truth of these beliefs. But it never demonstrates them in a strictly philosophical sense. Aureoli borrows an expression from Averroes to help him say what such rationes proba-

28. Aureoli Scriptum 1.1.2.92-128 (159-170).

29. 1 Peter 3.15 .

30. Augustine De Trinit. 14.1 (PL 42:1037; CCL 50A:421-422). 
biles accomplish. They help us to "imagine more clearly with our intellect" the revealed truths that we hold because of faith. ${ }^{31}$

Both the simple believer and the theologian believe the truths most firmly. But there is a difference between the two. The simple believer does not "intellectually imagine" or grasp his faith in any clear way, and this for a number of reasons. He does not understand the meaning of the terms, or he encounters objections to the faith which so entangle and confuse his mind that he cannot formulate exactly what he believes, or he doesn't have examples or analogies or any kind of parallels for what he believes, or he has no "probable reasons" to support him in his belief. A theologian surpasses a simple believer in just these respects: he has developed an ability to explain terms; he can consider and respond to objections; he is able to offer apt examples and supply probable arguments for the truths of faith. ${ }^{32}$

If one wishes to classify what a theologian does properly as theologian according to the Aristotelian division of intellectual virtues in book 6 of the Nicomachean Ethics, then it would be best not to call it science. For science gives evidence that forces our assent, whereas we already believe and do so on the authority of God revealing. What the theologian does should rather be called wisdom, for Aristotle describes wisdom as "the science of and insight into the things that are noblest by nature." 33 Now if Aristotle considers anything to have the character of wisdom, then surely it is metaphysics. He gives it that title in book 1 of his Metaphysics. ${ }^{34}$ At least in some parts of the Metaphysics, namely, in book 4, where he defends its principles, and in book 5 , where he explains its terms, Aristotle simply clarifies and defends the principles and terms. He does not demonstrate them or make them evident through syllogistic reasoning. ${ }^{35}$

A theologian performs a number of acts that show that he has developed many intellectual virtues or habits. He does at times demonstrate certain truths, not qua theologian, but qua metaphysican. In this activity he does produce science in regard to some truths about God. Furthermore, he makes many other deductions that render the 
content of the faith more explicit. Similarly he provides suitable theological opinion regarding the truths of faith. But in a more special and proper way a theologian qua theologian clarifies, defends, and offers probable arguments for the mysteries of faith, just as he explains the terms expressing these mysteries. Most properly, however, he provides insight. So declarative theology is wisdom, "the science of and insight into things which are the noblest by nature." It is not wisdom under the scientific aspect of wisdom but, rather, under the aspect of understanding or insight, for it brings light, understanding, or "insight into the noblest things by nature," i.e., the divine mysteries of our faith. ${ }^{36}$

It is no wonder that Augustine also gave this study the title of wisdom. He counts it the form of knowledge "by which that most wholesome faith is begotten, nourished, defended, strengthened"; and it knows how our faith "helps the pious and may be defended against the impious." 37 He has also called it "understanding," as in book 9 of the De Trinitate, where he locates this type of knowledge between simple faith and that certain knowledge which will be made perfect only after this life. In the same book he urges us "to seek to understand this mystery [of the Trinity], praying for help from God himself, whom we desire to understand; and as much as he grants, attempting to explain what we understand." 38 Augustine also calls this knowledge "the light of wisdom," as in his first homily On John's Gospel, where he informs us that God illumines the little ones in the Church with the light of faith, and the lofty souls, who are the mountains, with the light of wisdom. ${ }^{39}$

Richard of St. Victor, too, in the opening pages of his De Trinitate, urges us "to strive, insofar as we are able that we may understand [intelligamus] what we believe." 40 The opening chapter of the same work is his meditation on the text of Isaiah: "Unless you believe, you shall not understand [intelligetis]." 41

For Aureoli, in sum, the habit that is most properly acquired by the theologian is a habit distinct from faith. It does not cause our assent to

36. Aureoli Scriptum 1.1.3.129 (170).

37. Aüreoli Scriptum 1.1.3.127 (169).

38. Ibid.

39. Ibid.

40. Aureoli Scriptum 1.1.3.128 (169-170).

4I. Ibid. 
the articles of faith but presupposes such assent. Positively, it brings some understanding to our faith, makes it somewhat clearer, provides us with some imaginative understanding of the divine truths. Within the Aristotelian division of the intellectual virtues this properly theological habit should be considered wisdom, under the aspect of wisdom as insight or understanding, for it brings understanding, the light of wisdom, or "insight into the noblest things by nature." 42

Although Peter of Candia knew the detailed criticisms that both William of Ockham ${ }^{43}$ and Gregory of Rimini 44 brought against Aureoli, he limits his own evaluation of Aureoli's position to two points. First, no matter what arguments the theologian in his most proper work as a theologian might use in seeking to support the articles of faith, they will be probable reasons. On Aureoli's own admission they do not force our assent. What this means is that such arguments do not beget science or faith, otherwise they would command our assent; so they must beget opinion. Yet Aureoli himself argues that the most properly theological habit is not opinion, since if it were it would bring the hesitancy which is characteristic of opinion. In short, he seems to contradict himself. 45

Second, when Aureoli gives declarative theology the Aristotelian title wisdom he seems off the mark. If he takes wisdom in a metaphorical sense in view of some similarity between declarative theology and the Aristotelian view of wisdom, he would just as well be justified in calling declarative theology a jackass, since both a jackass and declarative theology have some similarity: they are both beings. If, on the other hand, he means that declarative theology is wisdom in the proper Aristotelian sense of the word, then he is deceived. For Aristotle wisdom is linked to evidence. It is even more directly linked to evidence than science is. Science is distinct from insight and gets its evidence from insight, whereas wisdom is not distinct from insight, at least in the sense that insight is one of its components: wisdom is "the science of and insight into the most noble things by nature." So, if Aureoli rejects Aquinas's theory of theology as a subaltern science because a subaltern science gives evidence, then a fortiori he ought to

42. Aureoli Scriptum 1.1.3.129 (170).

43. William Ockham Scriptum In I Sent. pro.7 (ed. Gál and Brown, 195-196).

44. Gregory of Rimini Sent. 1.pro.1.2 (ed. Venice, 1521, a2vK-a3vK).

45. Peter of Candia Sent. 1.pro. 1 (lines 117-147). 
reject wisdom as a proper title for his declarative theology, since wisdom all the more gives evidence. ${ }^{46}$ In short, theology is neither science nor wisdom in the strict Aristotelian senses of the terms.

Candia allows these observations to suffice as his direct criticisms of Aureoli's view. The overall weakness of Aureoli's position will appear more fully as our author argues for his own conception of theology. 47

\section{THE DEDUCTIVE THEOLOGY OF GREGORY OF RIMINI}

Peter Aureoli's declarative theology was also the main target of Gregory of Rimini's treatise. If an unbeliever uses what a Christian theologian like Aureoli calls probable reasons, he arrives at conclusions that are opinion. Since opinion is distinct from a properly theological habit, our fictive unbeliever would not develop a theological habit. Imagine for a moment that he becomes a believer. Automatically now he has a theological habit, and therefore a new habitus or developed ability, without developing through any further study anything he had not already developed within himself before. What wonderful magic!48

With this and similar arguments Gregory attempted to dismantle the theologia declarativa of Aureoli. In no way, however, did he think that he was undermining the theological procedures of Augustine or Richard of St. Victor, on whom he depended, as he attacked Aureoli's presentation:

I ask that Reverend Master whose opinion of what is proper theological discourse I have disproved to go back to the De Trinitate and find anywhere in that or in Augustine's other books places where he proves from probable propositions that God is three in one. I think he could not find any. But he'll only find what Augustine proved from the authorities of Scripture. . . . Let him go back and reread what he has read inattentively. ${ }^{49}$

Rimini's own attentive reading of Augustine, Dionysius the Areopagite, Hugh of St. Victor, and Peter Lombard led him to differ-

46. Peter of Candia Sent. 1.pro.1 (lines 148-169).

47. See the last section, below.

48. Gregory of Rimini Sent. 1.pro.1.2 (ed. Venice, 1521, a2vMN).

49. Gregory of Rimini Sent. 1.pro.1.2 (ed. Venice, 1521, a3rB). 
ent conclusions regarding the nature of theology and the role of the theologian. ${ }^{50}$

First off, he agreed with Aureoli that theology was not science in the strict Aristotelian sense of the term. Like Aureoli, Rimini follows Godfrey of Fontaines and Duns Scotus in their critique of the subaltern science theory of Aquinas and his followers. ${ }^{51}$ Theological study does not bring believers to evident knowledge of the truths of the faith, whereas science in both its subaltern and nonsubaltern forms produces evident knowledge. 52

Properly, theology extends the content of belief, and thus is not a habit distinct from faith. If a person accepts the truth of Sacred Scripture and furthermore is strong in intellectual habits, then reflection on Sacred Scripture will bring him to new conclusions. This is the situation with a theologian. He sees many truths that are not formally contained as such in Sacred Scripture but that follow necessarily from what is contained there. Now whether they are articles of faith or not, whether they are knowable through other sciences or not, and whether they are determined as revealed truths by the Church or not, he sees that they necessarily flow from what is formally revealed as such in Sacred Scripture. These are what Rimini means by theological conclusions. ${ }^{53}$

The theologian in his proper role sees that these truths demanded by intellectual reflection on the faith must be assented to with the same force of assent as the truths found in Sacred Scripture and that they must be admitted as unhesitatingly as the principles or premises found formally in Sacred Scripture itself. Theology thus extends the content of faith: it is a certain acquired faith. It is a habitus creditivus, a developed ability that extends our faith to its further logical and intelligible implications. ${ }^{54}$

Peter of Candia has no strong objection to this position of Rimini except for the exclusion that seems hidden in Rimini's attack on Aureoli. ${ }^{55}$ As we shall see in Candia's own conclusions concerning the

50. Gregory of Rimini Sent. 1.pro.1.2 (ed. Venice, 1521, a2vQ-a3vK).

5I. Gregory of Rimini Sent. 1.pro.1.2 (ed. Venice, 1521, a6vL-Q).

52. Ibid.

53. Gregory of Rimini Sent. 1.pro.1.2 (ed. Venice, 1521, a3rC, a2vQ-a3rD).

54. Peter of Candia Sent. 1.pro.1 (lines 171-179).

55. Peter of Candia Sent. 1.pro. 1 (lines 182-186). 
nature of theology, he agrees with Rimini's affirmative tendency. ${ }^{56}$ Rimini's fault, in Candia's eyes, is found in what he omits-in his imbalance.

\section{CANDIA'S OWN VISION \\ OF THE NATURE OF THEOLOGY}

Peter of Candia laid no claim to originality. He simply wished to steer a clear middle course between those who argue for too much, as with Aquinas's contention that theology is science in Aristotle's proper sense of that term, and those who argue for too little, as with those who might hold a theology of consequences. Even more specifically he wished to avoid the extreme of Aureoli's declarative theology, which denied that the proper role of the theologian was to extend the content of the faith ("nec habitus creditivus sed tantum declarativus"), and the extreme of Rimini's deductive theology, which considered the proper, and seemingly the only, role of the theologian was to extend the content of faith ("tantum creditivus"). 57

In choosing his middle road between these various extremes he chose as his guides those who led the way down the middle ("inter omnes mediando"): John Duns Scotus and William of Ockham. ${ }^{58}$ Following their principles, Candia chose a mediating role and presented a view of theology that avoided the excessive and exclusive accents in the positions of Aureoli and Rimini by fostering a marriage of declarative and deductive theology. 59

This marriage, in Candia's presentation, is not precisely a union of equal partners. Aureoli's declarative theology seems to have the upper hand. Three of Candia's first four conclusions are slanted in the direc-

56. See his fifth and sixth conclusions (lines 377-406).

57. Peter of Candia Sent. 1.pro.1 (lines 198-200).

58. Peter of Candia Sent. 1.pro.1 (lines 205-208). Cf. Scotus Sent. 3.24.1 (ed. Vivès, 15:36-49); William Ockham Scriptum in I Sent. pro.7 (ed. Gál and Brown, 183-206). For a general presentation of Scotus's position, see A. Magrini, Ioannis Duns Scoti Doctrina de Scientifica Theologiae Natura, Studia Antoniana 5 (Rome: Collegium Antonianum, 1952). A detailed analysis of Sent. 3.24 is given by L. Walter, Das Glaubensverständnis bei Johannes Duns Scotus (Paderborn: Schöningh, 1968), pp. 59-92. Ockham's prologue, q. 7, is given an excellent treatment by R. Guelluy, Philosophie et théologie, pp. 221-258.

59. Peter of Candia Sent. 1.pro.1 (lines 209-535). 
tion of declarative theology. In fact the first conclusion, that through theological study the student acquires a habit distinct from faith, is one of Aureoli's basic theses. ${ }^{60}$ Quite suitably, then, Candia's arguments supporting this conclusion are taken, fere verbotenus, from $\mathrm{Au}$ reoli's text. ${ }^{61}$ Furthermore, Candia's attack on Rimini in the first conclusion would appear to make deductive theology a lesser partner in the marriage. ${ }^{62}$ It is a very real partner even so, as Candia's fifth and sixth conclusions show. 63

For Candia there are two basic ways in which a theologian may approach the truths of revelation, and this is the ground for the union or marriage. He may either approach them as a unified message or else focus on the individual truths. Declarative theology favors the first approach, whereas deductive theology leans toward the second. 64

Declarative theology does not aim at extending the content of faith. It takes that content as it is and, following the urging of 1 Peter, it prepares the theologian to account for this faith. It makes him, in Augustine's phrase, able to show "in what way this belief itself may both help the pious and be defended against the impious." It also clarifies the meaning of the terms in the propositions expressing the truths of revelation and argues with probable reasons for these truths. Still, one of its principal tasks, Candia argues, makes it especially different from deductive theology: declarative theology focuses on the unified message. Accepting on faith the whole revelation with equal immediacy, the declarative theologian links together one truth within the revelation with another and shows how these mysteries hang together, how one implies the other, and how all are interrelated. Such collation of the mysteries of faith does not bring out or deduce new beliefs but shows the coherence of the mysteries. ${ }^{65}$

This developed ability permitting the theologian to account for this interrelation of the mysteries is distinct from faith itself, since the simple believer does not have the same facility. There is yet another sense in which such an ability is distinct from faith. None of the

6o. Peter of Candia Sent. 1.pro.1 (lines 209-264). Cf. Aureoli Scriptum 1.pro.1.96-111 (ed. Buytaert, 160-164).

6r. Peter of Candia Sent. 1.pro. 1 (lines 209-264).

62. Peter of Candia Sent. 1.pro. 1 (lines 243-264).

63. Peter of Candia Sent. 1.pro. 1 (lines 377-406).

64. Peter of Candia Sent. 1.pro. 1 (lines 252-264, 350-367).

65. Peter of Candia Sent. 1.pro. 1 (lines 350-376). 
declarative activities of a theologian brings about faith or makes him believe more firmly. He assents to the whole revelation because of his trust in the revealing God, not because of the harmony of the mysteries or the power of probable reasons. 66

If deductive theology seems slighted in Candia's early conclusions, then it receives a real legitimacy in his fifth conclusion. Although one way to look at the truths of the faith is to focus on the whole revelation with equal immediacy, there is another legitimate way of looking at the truths of faith. This second way is the procedure accented by Rimini's deductive theology. It takes the truths individually and looks at them as premises for deducing further truths of faith. In such a procedure the theologian abandons the equal immediacy of revelation and rather centers his attention on new truths in relation to the ones which are prior. The new ones are held through the medium of the prior ones. Our adherence to the derived truths is due to our adherence to the principles or premises. 67

For Candia both of these approaches are legitimate ways of considering the truths of faith. We can consider the divine revelation as truths of faith in themselves or as principles or premises for deriving further contents of our faith. Since both are legitimate ways of looking at divine revelation, it is false to speak of a declarative or deductive theology as though there were two distinct opposed theologies. We should rather speak of them as two legitimate and necessary theological habits or matured abilities that should be developed by all theologians. 68

Both these developed abilities are the properly theological habits that theologians develop through study in the theology faculty. They may also develop in their studies many other habits, such as the ones developed by metaphysicians or natural philosophers. Through these latter abilities theologians may acquire evidence of the truths they examine, but not qua theologians. ${ }^{69}$ Theologians, as theologians, through their declarative or deductive activities which are properly theological, do not acquire evidence. ${ }^{70}$ As Candia's formal answer to

66. Peter of Candia Sent. 1.pro. 1 (lines 282-299).

67. Peter of Candia Sent. 1.pro. 1 (lines 376-388).

68. Peter of Candia Sent. 1.pro.1 (lines 391-406).

69. Peter of Candia Sent. 1.pro. 1 (lines 407-442).

70. Peter of Candia Sent. 1.pro.1 (lines 483-494). 
I74 STEPHEN F. BROWN

the original question phrases it at the end of the prologue: "Through theological study only declarative and faith-extending habits are developed, and through these developed abilities no evident knowledge of the articles of faith is acquired."71

Boston College

7r. Peter of Candia Sent. 1.pro.3 (Bibl. Apostolica Vaticana lat. 1081, f. 20ra): "Per exercitium theologicum non adquiritur nisi habitus creditivus vel declarativus per quos de articulis fidei nulla notitia evidens adquiritur." 


\section{Appendix}

The Sentences-commentary of Peter of Candia exists in whole or in part in thirty-seven manuscripts. ${ }^{1}$ In the judgment of Ehrle the best manuscript is that contained in the Bibl. Apostolica Vaticana, cod. lat. 1081. ${ }^{2}$ Emmen also used the same manuscript as the base for his edition of Peter's question on the Immaculate Conception and demonstrated its undeniable superiority. ${ }^{3}$ We have used this manuscript for our present edition of the first question of Peter's prologue to book 1 of the Sentences. Any alterations that we have made to the text are found between angle brackets, \langle\rangle . The text we have edited is found on ff. 9ra-12rb.

\section{〈PETRI DE CANDIA}

\section{PROLOGUS LIBRI SENTENTIARUM $\rangle$}

Super materiam prologi totius Sententiarum libri generalis incipit quaestio. Circa prologum in quo communiter quaerunt doctores de habitu per studium theologicum adquisito, quaero istam quaestionem: utrum intellectus viatoris per exercitium theologicum adquirat evidentem notitiam de credibilibus revelatis.

Et arguo quod non tribus mediis, et primo sic: ex nullis propositionibus probabilibus vel simpliciter creditis adquiritur evidens notitia; sed totum theologicum exercitium est circa probabilia vel simpliciter credita; ergo quaestio falsa. Consequentia patet. Et maior declaratur, quoniam ex probabilibus causatur opinio et ex credibilibus fides; sed tam fides quam opinio sunt habitus inevidentes, aliter habentes opiniones vel credulitates de conclusionibus contradictoriis haberent notitias evidentes, quod videtur falsum. Sed minor probatur

I. Emmen, "Petrus de Candia," pp. 247-250.

2. Ehrle, Der Sentenzenkommentar, p. 21.

3. Emmen, "Petrus de Candia," pp. 261-266. 
sic: omne intellectuale exercitium vel est commune elenchum, vel topicum, sive demonstrativum, vel sophisticum, ut 20 patet per Philosophum sufficienter dividentem intellectuale exercitium in libris logicae disciplinae. ${ }^{4}$ Sed constat quod theologicum exercitium non est commune 〈elenchum), nec demonstrativum vel sophisticum: ergo per sufficientem divisionem quadrimembrem et remotionem trium partium se25 quitur quod est topicum vel probabile sive creditivum, quod erat probandum.

Praeterea, et secundo arguo sic: quodlibet statui viae incompossibile repugnat intellectui viatoris; sed evidens notitia de credibilibus revelatis est huiusmodi; ergo quaestio falsa.

30 Consequentia et maior patent. Sed minor probatur sic: quorum rationes formales contradicunt et ipsa sunt ad invicem incompossibilia; sed ratio formalis fidei evidenti notitiae contradicit, ut patet per A postolum, Ad Heb. 11, 5 fidem taliter describentem: Fides est substantia rerum sperandarum, argumen-

35 tum non apparentium; ergo fides et notitia evidens sunt ad invicem incompossibiles. Nunc vero fides est statui viae annexa, ut patet per Apostolum, I Ad Cor. 13:6 Videmus nunc per speculum et in aenigmate; tunc autem facie ad faciem. Ergo notitia evidens veritatum credibilium est statui viae incom40 possibilis, quod erat probandum.

Praeterea, et tertio, arguo sic: quaelibet notitia ponens viatorem in termino repugnat viatori; sed evidens notitia veritatum credibilium est huiusmodi; ergo quaestio falsa. Consequentia et maior patent. Et minor probatur: quodlibet statui 45 patriae annexum de necessitate ponit habentem illud in patria; sed evidens notitia 〈veritatum credibilium) est de necessitate statui patriae annexa, iuxta illud Ioan 17: ${ }^{7}$ Haec est vita aeterna, ut cognoscant te, solum Deum verum. Quae auctoritas non potest intelligi nisi de notitia evidente, cum 〈nulla) alia 50 sit nobis pro statu viae possibilis. Ergo evidens notitia veritatum credibilium ponit habentem illam in termino.

4. Aristotle Topics 1.1.100a18-b24; cf. On Sophist. Refut. 2.165a34-b12.

5. Hebrews 11.1.

6. Corinthians 13.12 .

7. John 17.3. 
Ad oppositum, et pro veritate quaestionis, arguo tantum unico medio: omnis habitus intellectualis est sapientia, vel intellectus, scientia vel prudentia, ars, fides vel opinio. Sed constat quod per exercitium theologicum aliquis habitus adquiritur, aliter esset studium otiosum. Et non fides, quia aeque bene habetur sine tali studio sicut cum tali, ut patet de vetulis et simplicibus Christianis. Nec opinio, cum includat formidem, et est contra statum fidelis, nam ut dicitur Extravagantes, 'De haereticis' 8 "Dubius in fide infidelis est." Nec ars, cum sit respectu factibilium, ut dicitur VI Ethicorum. ${ }^{9}$ $\mathrm{Nec}$ prudentia, quia tunc maiores theologi essent prudentiores, cuius oppositum experimur. Ergo adquiritur vel sapientia, 〈vel〉 intellectus, vel scientia; quorum si aliquod detur, habetur propositum, cum quilibet praemissorum habituum sit habitus evidens, ut ex ipsorum definitionibus potest clarius apparere.

\section{$\langle$ DIVISIO PROLOGI〉}

Pro decisione quaestionis istius iuxta materiam trium argumentorum ad quaestionis oppositum adductorum tres erunt articuli pertractandi, quorum primus, iuxta materiam primi argumenti: Utrum habitus theologiae sit tantum creditivus seu probabilis in studente, vel sic: Utrum habitus per exercitium theologicum adquisitus sit evidentis notitiae portio substantiva. Secundus, iuxta secundi argumenti materiam: Utrum in intellectu studentis theologiam fides et scientia possint simul exsistere subiective, vel sic: Utrum in eadem mente respectu eiusdem obiecti fides et evidens notitia possint simul exsistere subiective. Tertius, iuxta materiam tertii argumenti: Utrum studenti theologiae, ut viator est, repugnet cognitio scientifica credibilium veritatum, vel sic: Utrum veritatum credibilium evidens notitia viatorum statui formaliter sit repugnans.

8. In 'Extravagantibus primis,' that is, in Compilatione I (= Breviarium extravagantium Bernardi Papiensis, c. 1187-1191), ed. A. Augustini, Antiquae decretalium collectiones (Paris, 1621), 123; following Decretales Greg. IX, lib. V, tit. 7 "De hereticis," cap. 1 (ed. A. Friedberg, Corpus Iuris Canonici, 2:778).

9. Aristotle Nic. Ethics 6.4.1140a1-23. 


\section{〈ARTICULUS PRIMUS〉}

Pro declaratione primi articuli sic procedam: primo quorundam doctorum opiniones praemittam; secundo eliciam seu conflabo positionem meam per certas conclusiones; ex quibus patebit quid sentio de materia quaestionis.

〈I. OPINIONES ALIQUORUM DOCTORUM: OPINIO PETRI AUREOLI $\rangle$

Quantum ad primum est advertendum quod dominus frater Petrus Aureoli, Scripto suo primo super Sententias, prima questione prologi, articulo secundo, ${ }^{10}$ sententiali-

95 ter sic imaginatur, dicens quod in sacra scriptura est multiplex processus: quandoque ad propositionem scitam, quandoque ad creditam, quandoque ad credendam. Et secundum hoc potest imaginari septuplex processus, videlicet triplex simplex et quadruplex compositus. Simplex $\langle$ est $\rangle$ vel ex propositionibus

100 necessariis tantum vel ex probabilibus tantum, vel ex simpliciter creditis tantum. Compositus seu mixtus est vel ex omnibus simul, vel ex una necessaria et altera probabili, vel ex una necessaria et altera credita, vel ex una credita et altera probabili. Ex quibus dicit quattuor theologica documenta: 105 primum, quod in primo processu adquiritur habitus scientificus. Secundum, quod in secundo processu adquiritur habitus dumtaxat probabilis. Tertium, quod in tertio processu adquiritur habitus tantummodo creditivus. Quartum quod in quarto processu, quo videlicet proceditur ex omnibus simul, et

110 cum hoc adducuntur rationes et dubia persolvuntur, adquiritur proprie habitus theologicus. Quod qualis sit quattuor ponit conclusiones. Prima, quod habitus huiusmodi est alius a fide. Secunda, quod non est habitus adhaesivus. Tertia, quod est habitus dumtaxat declarativus. Quarta, quod est huiusmodi 115 habitus habet vere rationem sapientiae virtutis intellectualis.

\section{〈CONTRA OPINIONEM PETRI AUREOLI〉}

Licet illa positio videatur probabilis quoad multa, tamen quoad duo ipsius dicta quae mihi in hac parte 
non videntur vera arguam contra ipsam. Primum, in hoc quod dicit quod ex omnibus propositionibus, videlicet probabilibus, necessariis et creditis, generatur habitus theologicus. Contra hoc arguo sic: quilibet habitus discursive causatus ex habitibus vel propositionibus differentibus secundum perfectionem semper sequitur naturam minus perfecti. Sed habitus discursive causatus ex propositionibus necessariis, probabilibus et simpliciter creditis simul est habitus discursive causatus ex habitibus vel propositionibus differentibus secundum perfectionem; ergo huiusmodi habitus sequitur naturam habitus minus perfecti. Cum igitur inter omnes habitus probabilis sive creditivus sit minus perfectus, sequitur quod habitus huiusmodi erit aut creditivus aut probabilis et per consequens non theologicus iuxta suam imaginationem. Maior huius rationis patet ex hoc quia in omni discursiva mixtione semper conclusio sequitur naturam minus perfectae aut debilioris praemissae, ut vult $\mathrm{Ph}$ ilosophus, ${ }^{11}$ et omnes logicae tractatores. Et minor est de se nota; ergo etc.

Confirmatur exemplariter, nam formata copulativa cuius una pars sit necessaria et altera contingens in forma syllogistica, conclusio sequens de necessitate erit contingens. Verbi gratia: omne ens est substantia; Sortes est ens; ergo Sortes est substantia. Constat manifeste quod conclusio quae contingens dinoscitur, videlicet 'Sortes est substantia', non naturam imitatur propositionis necessariae sed potius contingentis, et ita regulariter in omni syllogistica mixtione reperies; ergo ad praedicta conformiter habitus discursive causatus ex omnibus praemissis simpliciter sequitur naturam habitus minus perfecti, quod erat probandum.

Secundum dictum suum quod mihi non placet 〈est hoc) quod est eius quarta conclusio, videlicet habitus theologicus habet vere rationem sapientiae virtutis intellectualis. Contra hoc arguo sic: vel accipit sapientiam proprie vel metaphorice. Si metaphorice, nihil ad propositum, 〈quia) sic posset vocare habitum theologicum asinum, propter quandam similitudinem quam habet cum asino, quia quilibet eorum est ens. Si autem accipit proprie; contra: omnis habitus sapientialis est ad- 
haesivus, cum sit evidens; sed per ipsum ex sua conclusione secunda habitus theologicus non est adhaesivus, ergo per consequens nec sapientialis. Praeterea, si habitus theologicus esset sapientia proprie, tunc esset evidentior habitu scientifico,

160 quia scientia capit evidentiam ab intellectu; nunc autem sapientia est intellectus et scientia simul, ut vult Philosophus, VI Ethicorum. ${ }^{12}$ Consequens est falsum, etiam secundum eum, nam in pugnando dicta Sancti Thomae qui tenet quod habitus theologicus habet rationem scientiae subalternae dicit quod

165 hoc non potest esse per hoc quod omnis scientia causat evidentiam, cuiusmodi non facit habitus theologicus. ${ }^{13}$ Ergo, si loquatur proprie, sibi ipsi contradicit; si vero improprie, nihil ad propositum. Et $\langle$ haec $\rangle$ tantum de ista positione, quia improbando dicta mea etiam improbabuntur haec dicta.

Ulterius est Gregorius de Arimino qui dicit quattuor circa propositam quaestionem, prima quaestione prologi, articulo quarto. ${ }^{14}$ Primum, quod ex discursu theologico non adquiritur scientia. Secundum, quod adquiritur 175 adhaesio. Tertium, quod adquiritur adhaesio sine formidine. Quartum, quod adquiritur 〈habitus creditivus〉 sive fides. Ex quo patebit ${ }^{15}$ quod huiusmodi habitus theologicus qui communiter adquiritur est quidam habitus creditivus et fides quaedam adquisita.

Haec positio quoad ultimam suam conclusionem, si intelligatur cum exclusione, ut ipse videtur dicere arguendo etiam contra positionem domini Petri Aureoli, non videtur vera. Cuius improbatio apparebit ex probatione conclusionum mearum.

12. Aristotle Nic. Ethics 6.7.1141b2-3.

13. Aureoli Scriptum 1.pro.1.30 (ed. Buytaert, 1:140).

14. Gregory of Rimini Sent. 1.pro.1.2 (ed. Venice, 1521, a2vK-A3vK).

15. patebit] dicit add. cod. 
〈OPINIO BEATI THOMAE AQUINATIS〉

Alii dixerunt quod habebat rationem scientiae subalternae, ut beatus Thomas. ${ }^{16}$

〈OPINIO IOANNI DE NEAPOLI ATTRIBUTA〉

Aliii ${ }^{17}$ 〈vero dixerunt〉 quod est tantum notitia consequentiarum.

\section{〈OPINIONES IN GENERALI〉}

Unde generaliter quidam ${ }^{18}$ tenent quod habitus theologiae est scientia; et quidam ${ }^{19}$ quod non. Tenentes negativam $\left\langle\right.$ aliqui ${ }^{20}$ dicunt quod non est creditivus; alii ${ }^{21}$ quod sic. Vult igitur beatus Thomas quod theologia sit scientia proprie dicta. Vult dominus Petrus Aureoli quod non sit scientia, nec habitus creditivus sed tantum declarativus. Vult Gregorius quod sit tantum creditivus.

\section{〈II. RESPONSIO AUCTORIS〉}

Omissis igitur positionibus istorum doctorum quae mihi in certis suis dictis non placent, venio ad illud quod mihi videtur magis consonum veritati et prout potest colligi ex dictis Doctoris Subtilis, III Sententiarum, distinctione 24, ${ }^{22}$

16. Thomas Aquinas Summa theologiae 1.1.2.

I 7. John of Naples Quaestiones variae Parisiis disputatae 18.3.5 (ed. Naples, 1618, 154): "Si vero loquamur de hac doctrina quantum ad suas conclusiones, sic etiam dicendum est quod est scientia proprie et stricte. Scimus enim quod conclusiones huius doctrinae necessario sequuntur ex suis principiis. Sic ergo patet quod haec doctrina potest dici scientia quinque modis. . . . Quinto potest dici scientia consequentiarum; scit enim theologus quod conclusiones theologiae necessario sequuntur ex suis principiis."

18. Thomas Aquinas Summa theologiae 1.1.2.

19. Averroes In Aristot. Metaph. 2.1 (ed. Juntas 8:14rb-va); In Aristot. De anima 3.36 (ed. F. S. Crawford, 494-495). This opinion is attributed to Averroes by Henry of Ghent Summa 4.5 (ed. Paris, 1520, 1:32B-33E).

20. Aureoli Scriptum 1.pro.1.96-111 (ed. Buytaert, 1:160-164).

21. Gregory of Rimini Sent. 1.pro.1.2 (ed. Venice, 1521, a2vK-a3vK).

22. John Duns Scotus Sent. 3.24.1 (ed. Vivès, 15:36-49). 
et Venerabilis Inceptoris Ockham, quaestione septima prologi, ${ }^{23}$ inter omnes mediando, pro cuius ${ }^{24}$ declarationes septem pono conclusiones.

Prima conclusio: intellectus viatoris per exercitium 210 theologicum adquirit habitum ultra fidem. Haec conclusio sic probatur: positis causis sufficientibus et non impeditis ad productionem alicuius effectus 〈necessario〉 ponitur ille effectus; sed propositiones in sacra scriptura contentae cum propositionibus aliis naturaliter adquisitis et lumen naturale intellectus

215 agentis quo intellectus exercitatur in declarando et exponendo sacram scripturam sunt causae sufficientes ad productionem certi habitus; ergo his positis in intellectu studentis theologiae necessario causabunt aliquem habitum, et non fidem, quia, ut suppono, illam prius habebat; ergo aliquem alium, quod est 220 propositum. Si dicatur quod licet non adquirat fidem, tamen augmenta est; contra: omnis habitus adhaesivus per aliquod tempus augmentatus in fine illius temporis firmius adhaeret per illum habitum habens eum quam prius; patet de se. Sed in fine exercitii theologici non firmius quis adhaeret quam ante,

225 ut experientia docet; ergo propositum.

Praeterea, quicumque habet aliquem actum intellectus in sua potestate $a b$ actu assentiendi distinctum respectu creditae veritatis habet alium habitum a fide. Sed exercitatus in theologia habet actum huiusmodi, ergo conclusio vera. Con230 sequentia patet, et maior est Philosophi, II De anima, ${ }^{25}$ dicentis quod habitibus operamur cum volumus. Et minor declaratur, quoniam iste sic exercitatus novit reddere rationem et fidem defensare et infirmos roborare. Sed constat quod isti actus sunt valde distincti ab actu assentiendi, aliter hos actus haberent similiter simplices fideles, quod non videtur verum; ergo conclusio vera.

Praeterea, frustra fit per plura quod potest fieri per pauciora. ${ }^{26}$ Sed si per exercitium theologicum nullum alium habitum a fide adquirit studens in theologia, sequitur quod

23. William Ockham Scriptum in I Sent. pro.7 (ed. Gál and Brown, 195-196).

24. cuius corr. cod. ex quaestione interl. (al. man.).

25. Aristotle On the Soul 2.5.417b23-24.

26. Aristotle Physics 1.4.188a17-18. 
huiusmodi exercitium est frustra, cum sine tali potest adquirere talem habitum, ut simplices fideles faciunt; ergo praeter habitum fidei oportet ponere alium habitum in studente.

Ex hac conclusione apparet falsitas opinionis Gregorii, si intelligat conclusionem suam universaliter, ut apparet. Unde advertendum est quod opinantem decipit hoc, quia omnis propositio vel est necessaria et evidens vel probabilis vel credita, ideo imaginatur quod ex his simul non potest sequi nisi credita vel probabilis, et quod propositionum quae in theologico exercitio sumuntur communiter altera illarum est credita. Ideo dicit quod ex his simul non potest adquiri aliud quam habitus creditivus.

Propterea dico quod ex propositionibus aliquem habitum causari contingit dupliciter: vel illative vel collative. Verbi gratia, nunc adhaereo certae conclusioni in sacra pagina contentae, et postea per aliquam propositionem sacrae scripturae infero illam. Tunc de illa propositione causatur in me, si actus fuerit frequentatus, habitus quo adhaereo, et iste est causatus illative. Secundo modo possum adhaerere omnibus propositionibus contentis in sacra scriptura, non uni propter aliam sed omnibus aeque immediate; tunc conferendo unam cum alia, ex isto frequenti actu causatur in me unus habitus, qui non est fides, quo reddo rationem de his quae continentur in sacra pagina, et istum modum forsan non viderunt oppositum affirmantes.

Secunda conclusio: habitus huiusmodi taliter adquisitus sub evidenti notitia minime continetur. Haec conclusio sic probatur: nullus habitus qui potest stare cum errore est evidens notitia; sed habitus huiusmodi taliter adquisitus potest stare cum errore; ergo conclusio vera. Consequentia patet; et maior probatur ex hoc, quoniam omnis notitia evidens vel est necessaria vel contingens; sed nulla notitia evidens necessaria potest stare cum errore, cum illa sit vel sapientia, 〈vel〉 intellectus, vel scientia, qui sunt habitus de necessitate veridici. Nec etiam contingens, quia licet talis posset non esse, non tamen staret quod esset evidens et erronea, igitur simpliciter maior vera. Minor vero declaratur, nam signo certum magnum theologum qui postmodum efficiatur hereticus; certum est quod licet iste perdat habitum creditivum, non tamen 
illum per quem sciebat sacram scripturam exponere. Ergo ille 280 habitus ita stat cum errore sicut sine errore; et per consequens conclusio vera.

Praeterea, omnem habitum quem potest naturaliter adquirere fidelis potest et infidelis; sed huiusmodi habitum potest naturaliter adquirere fidelis; ergo et infidelis. Maior patet,

285 quoniam individua eiusdem speciei aeque naturaliter possunt. Minor vero apparet, quia omnis talis habitus potest adquiri a parvulo 〈infideli〉 inter fideles nutrito. Et tunc ultra ab infideli potest adquiri talis habitus respectu credibilium 〈veritatum), et non evidens notitia, quia sic firmissime adhaereret, et ita 290 non esset infidelis, quod est contra suppositum.

Praeterea, omnis habitus evidens inducit certitudinem ultra fidem; sed talis habitus 〈theologicus〉 non inducit certitudinem ultra fidem; ergo conclusio vera. Consequentia et maior patent; et minor declaratur, quoniam habens talem habitum non

295 firmius adhaeret per talem habitum et fidem quam per solam fidem; ergo propositum. Consequentia patet; et antecedens est notum de studentibus in theologia qui non experiuntur se firmius adhaerere huic 'Deus est trinus et unus' post exercitium theologicum quam ante; ergo propositum.

300 Tertia conclusio: habitus huiusmodi taliter adquisitus non exsistit habitus adhaesivus. Haec conclusio sic probatur: omnis habitus adhaesivus est sapientia, intellectus, scientia, fides vel opinio. Sed habitus huiusmodi non est sapientia, intellectus vel scientia, nec fides nec opinio; ergo conclusio

305 vera. Consequentia patet; et maior declaratur, quoniam omnis adhaerens alicui aut adhaeret propter evidentiam necessariam aut contingentem. Si primo modo, aut illa est evidentia principiorum, et sic est intellectus, aut conclusionum, et sic est scientia, aut tam principiorum quam conclusionum, et sic est

310 sapientia, ut vult Philosophus, VI Ethicorum. ${ }^{27} \mathrm{Si}$ secundo modo aut adhaeret ex notitia intuitiva singularium, et sic habetur communis notitia contingentium, ut videndo Sortem et albedinem adhaereo 〈huic): quod Sortes est albus. Aut ex auctoritate dicentis, et sic est fides. Aut adhaereo ex aliquali 315 rerum apparentia, et sic opinio causatur. Sed minor de- 
claratur, nam iste habitus ex quo per secundam conclusionem non est evidens sequitur quod nec sapientia, intellectus, vel scientia. Nec est fides, ut dicit prima conclusio. Nec est opinio, quia huiusmodi habitus includit formidem et per consequens repugnat fidei. Sed iste habitus stat cum fide; ergo minor vera et per consequens conclusio.

Praeterea, omnis habitus adhaesivus causatur illative vel ex propositionibus necessariis vel probabilibus vel simpliciter creditis vel ex experientia rerum. Sed huiusmodi habitus non causatur ex aliquo istorum 〈modorum〉 illative, nec ex experientia rerum; ergo conclusio vera. Consequentia et maior patent. Et minor declaratur, quoniam, ut dictum est in declaratione primae conclusionis, huiusmodi habitus causatur collative potius quam illative. Nec etiam habetur ex experientia, proprie loquendo de experientia qua quis certificatur ut apparet; ergo propositum.

Praeterea, si habitus huiusmodi esset adhaesivus, aut convertibiliter, aut disparate, aut secundum superius et inferius, aut per accidens. Sed nullum illorum modorum est verum; ergo conclusio vera. Consequentia et maior patent.

Et minor probatur: non primo modo, quia tunc omnis habitus adhaesivus esset huiusmodi habitus; quod est falsum. Nec secundo modo, quia sic nullo modo possunt convenire. Nec tertio modo, quia quandocumque aliqua se habent secundum superius et inferius, quidquid potest praedicari de superiori universaliter potest et de inferiori; sed de habitu adhaesivo universaliter sumpto praedicatur sufficienter hoc disiunctum: sapientia, vel intellectus, vel scientia, vel fides vel opinio; ergo et posset praedicari de habitu huiusmodi; quod est falsum, ut in prima ratione ostensum est. Nec quarto modo, quia tunc accidens esset subiectum accidentis, quod non communiter est concessum, nam si iste habitus est adhaesivus per accidens huic habitui inhaereret adhaesio qua formaliter est adhaesivus, et sic accidens est subiectum accidentis; patet igitur conclusio.

Quarta conclusio: habitus huiusmodi taliter adquisitus est theologicus proprie, qui potest declarativus merito nuncupari. Haec conclusio sic probatur, et primo quoad primam partem, videlicet quod sit theologicus: quilibet habitus causatus ex exercitio alicuius facultatis dicitur pertinere ad 
355 illam facultatem, sicut habitus causatus ex exercitio geometrae dicitur esse geometricus et ex exercitio logicae logicus, et sic de similibus. Sed iste habitus, ut prius apparuit, causatur ex collatione propositionum contentarum in sacra scriptura; ergo est vere theologicus. Quoad secundam partem similiter pro-

360 batur conclusio, videlicet quod sit declarativus: omnis habitus inducens explicationes terminorum, solutiones dubiorum, exempla et manuductiones est vere declarativus; sed habitus huiusmodi est talis; ergo conclusio vera. Consequentia et maior patent. Et minor declaratur, quoniam exercitatus in 365 theologia hoc habet ultra simplicem fidelem: quod novit rationem reddere de his quae continentur in sacra scriptura, et similiter defensare; quare propositum.

Haec conclusio expresse est de mente beati Augustini, XIV De Trinitate, cap. primo, ${ }^{28}$ ubi hunc habitum vocat scien-

370 tiam, large tamen sumendo scientiae nomen, ubi sic dicit: "Hac scientia non pollent fideles plurimi, quamvis polleant ipsa fide plurimum. Aliud est enim scire tantummodo quid homo credere debeat propter adipiscendam vitam beatam quae nonnisi aeterna est; aliud autem, scire quemadmodum

375 hoc ipsum et piis opituletur et contra impios defendatur." Haec ille. Ex quibus apparet veritas conclusionis.

Quinta conclusio: praeter habitum superius nominatum per theologicum exercitium adquiritur creditivus habitus qui theologicus potest similiter nominari. Haec conclusio sic pro-

380 batur: omnis habitus causatus ex propositionibus in sacra scriptura contentis est theologicus; sed habitus creditivus est huiusmodi; ergo conclusio vera. Minor vero probatur, quoniam ex propositionibus in sacra scriptura contentis discursive infero unam propositionem cui per prius non adhaerebam et

385 nunc adhaereo; sed constat quod huiusmodi adhaesio non excedit fidem, cum adhaesio conclusionis non excedat adhaesionem illius unde causatur; ergo simpliciter ex tali discursu adquiritur habitus creditivus.

Ista conclusio expresse videtur de mente Salvatoris, Ioan $39020: 29$ Haec scripta sunt $u$ t credatis, et ut credentes vitam habeatis.

28. Augustine De Trinitate 14.1 (PL 42:1037; CCL 50A:421-422).

29. John 20.31. 
Sexta conclusio: habitus theologicus per creditivum et declarativum habitus dividitur adaequate. Volo dicere quod omnis habitus theologicus 〈vel〉 est creditivus vel declarativus. Haec conclusio sic probatur: omnis habitus causatus ex propositionibus in sacra scriptura contentis vel causatur discursive vel illative-seu collative; sed omnis habitus theologicus est habitus causatus ex propositionibus in sacra scriptura contentis; ergo omnis habitus theologicus vel causatur discursive vel collative. Ergo est creditivus vel declarativus. Probo istam consequentiam, quia omnes propositiones in sacra scriptura contentae vel sunt necessariae et evidentes vel creditae. Sed constat quod ex his discursive nihil aliud adquiritur quam habitus creditivus; ergo propositum. Si vero sit inter eas collatio, non adhaerendo uni propter aliam sed ipsas dumtaxat ad invicem conferendo, tunc certum est quod adquiritur habitus tantum declarativus; ex quibus patet conclusionis veritas.

Septima et ultima conclusio est haec: praeter habitus superius nominatos per exercitium theologicum adquisitos possunt de veritatibus theologiae adquiri plures habitus non theologici ad diversas scientias pertinentes. Haec conclusio sic probatur: in sacra scriptura continentur non solum veritates speculativae sed etiam practicae, non solum necessariae sed etiam probabiles et contingentes. Sed constat quod de primis, videlicet speculabilibus et necessariis, utpote "Deus est actus purus," "Deus est summum bonum" habetur notitia evidens et scientifica causata ex propositionibus necessariis evidenter notis lumine naturali, ut patet per argumenta philosophantium quae fiunt $a b$ effectu ad causam demonstratione quia; ergo de ipsis causatur habitus scientificus. Et sicut ex veritatibus speculativis scientificus habitus 〈habetur〉, ita ex moralibus practicus. Et sic de aliis habitus varii causantur, et per consequens conclusio quoad primam partem $\langle$ est $\rangle$ vera.

Quod autem huiusmodi habitus non sint theologici patet ex praedictis, quoniam habitus (proprie) theologicus viatoris secundum communem cursum naturae non est evidens. Et dico signanter 'habitus viatoris secundum cursum naturae' ad differentiam habituum comprehensorum qui sunt evidentessimiliter, ad differentiam habituum qui possunt alicui infideli praeter cursum naturae ex omnipotentis imperio voluntatis: 
430 quales fuerunt infusi beato Paulo in raptu, qui secundum communem doctorum opinionem fuerunt evidentes; de quarum notitiarum differentia loquitur Apostolus, I Ad Corinthios 13:30 Videmus nunc per speculum et in aenigmate-quoad viatores; tunc autem facie ad faciem-quoad comprehensores. Est

435 ergo conclusionis intentio 〈loqui〉 de habitu adquisito per exercitium theologicum a viatore secundum cursum naturae; qui habitus est proprie theologicus cum sit causatus ex propositionibus revelatis et necessariis ad aeternam beatitudinem consequendam, et iste non alius in genere quam creditivus vel

440 declarativus dinoscitur, ut superius est expressum. Constat autem quod praemissi habitus sunt evidentes, ergo non theologici, et per consequens tota conclusio vera.

Ex qua positione apparet facillime, et sequitur correlarie, quod habitus theologiae non est scientia proprie dicta: contra

445 positionem beati Thomae. Similiter, quod praeter habitum creditivum adquiritur habitus alius a fide: contra opinionem Gregorii. Similiter, quod adquiritur habitus adhaesivus: contra opinionem domini Petri Aureoli. Sequitur quarto quod non est opinio-contra aestimationem philosophorum 450 communiter opinatam.

\section{〈DUBITATIONES ET SOLUTIONES EARUM〉}

Quamvis autem istae conclusiones videantur verae, tamen est dubium de duabus conclusionibus ultimis, videlicet sexta et septima. Primum dubium est circa sextam 455 conclusionem, quod non videtur verum quod habitus theologicus sit sufficienter divisus in creditivum et declarativum, cum omnis ille habitus sit theologicus qui causatur ex propositionibus theologicis. Nunc vero multae sunt veritates theologicae naturaliter cognoscibiles, ut 'Deus est sapiens,' et sic 460 de multis aliis; ergo habitus adquisitus non est creditivus sed evidens in lumine naturali. Quod autem tales veritates sint theologicae apparet, quia sunt necessariae ad aeternam beatitudinem consequendam, et tales vocat theologicas beatus Augustinus, XIV De Trinitate, cap. 1. ${ }^{31}$

30. 1 Corinthians 13.12 .

31. Augustine De Trinitate 14.1 (PL 42:1037; CCL 50A:421-422). 
Secundum dubium est quia si multi habitus de veritatibus theologiae adquirerentur ad diversas scientias pertinentes, ut innuit conclusio septima, tunc idem habitus esset theologicus et metaphysicus, quod non videtur verum.

Ad primum istorum dico quod licet multae veritates theologicae sint naturaliter cognoscibiles, non tamen ut theologicae theologia viatoris. Unde habens utrumque habitum, tam videlicet creditivum quam declarativum, etiam si nullam talem veritatem cognosceret in lumine naturali, non minus adhaereret eidem. Dico igitur quod licet eandem veritatem possimus cognoscere diversis viis, non tamen sequitur quod habitus theologicus sit evidens, sed sequitur quod respectu eiusdem veritatis possunt esse diversi habitus per diversos discursus generati.

Unde pro maiori praedictorum declaratione advertendum est quod multae sunt veritates theologicae quarum notitia non habetur per exercitium theologicum. Verbi gratia, hae sunt veritates theologicae: 'Deus est supremum ens,' 'Deus est id quo melius excogitari non potest.' Et tamen per exercitium quod quis habet in sacra scriptura non adquirit illarum veritatum notitiam, quoniam absque tali exercitio habetur talium veritatum notitia, ut patet in viris scientificis qui aliunde talium veritatum notitiam sunt adepti. $\mathrm{Si}$ autem quis per exercitium sacrae scripturae primo caperet praedictarum veritatum notitiam, tunc talis notitia esset theologica et non evidens, tamen ipsius notitia ex propositionibus dumtaxat creditis causaretur. Unde si postea se in aliis scientiis exercitaret, utpote philosophiae naturalis aut metaphysicae, tunc adquireret illarum veritatum notitiam evidentem, et priorem amitteret, theologicam videlicet creditivam. Sicut tenens per fidem quod triangulus habet tres angulos aequales duobus rectis, si postea se exercitet in geometria adquiret habitum evidentem de illa conclusione, per cuius adquisitionem desinet prima notitia tantummodo creditiva. Et si non subito quoad substantiam habitus tamen quoad potentiam perceptivam totaliter immutat, prout in sequenti dicetur articulo. ${ }^{32}$ Similiter, viator nunc tenet per fidem quod Deus est trinus et unus. 
Cum autem pervenerit ad patriam habebit praemissae veritatis notitiam evidentem, et tunc evacuatur notitia creditiva iuxta illud Apostoli, I Ad Cor. 14:33 Cum autem venerit quod per-

505 fectum est evacuabitur quod ex parte est. Non ergo habeo pro aliquo inconvenienti quod aliquae veritates theologicae sint viatoribus evidenter notae. Sed bene haberem pro inconvenienti quod veritates huiusmodi, naturaliter videlicet cognoscibiles, essent viatoribus evidenter notae theologia viatoris

510 secundum cursum naturae. Unde non sequitur: haec veritas est theologica, ergo eius notitia est theologica, theologia videlicet viatoris secundum cursum naturae. Propter quod concedendae sunt istae propositiones: 'aliqua notitia de veritatibus theologiae non est theologica,' 'aliqua est veritas theologica

515 cuius notitia non adquiritur per exercitium theologicum viatoris,' 'alicuius veritatis naturaliter cognoscibilis adhaesio est viatori necessaria ad aeternam beatitudinem consequendam.'

Et per praedicta patet responsio ad secundum dubium:

520 quod nullum est inconveniens eandem veritatem ad diversas facultates vel scientias, sumendo nomen scientiae largo modo, pertinere. Verbi gratia, simplex fidelis habet istam 'Deus est unus' ex fide, ut dicitur in symbolo 'Credo in unum Deum,' et sic dicitur theologica. Metaphysicus vero demonstrat eandem,

525 ut patet, XII Metaphysicae:34 "Entia neque volunt male disponi, unus ergo princeps." Et sic respectu eiusdem veritatis sunt metaphysicus habitus et theologicus, et ita eadem veritas ad diversas reducitur facultates. Et si dicatur: quomodo respectu eiusdem habetur habitus evidens et inevidens, meta-

530 physicus videlicet et theologicus; dicitur quod hoc pervenit ex varietate subiectorum, nam unitas obiectiva varietati non obviat subiectivae. Sed utrum stante unitate tam ex parte obiecti quam subiecti sit possibilitas, de hoc nihil ad praesens, quia in sequenti articulo ista materia declarabitur. Ex quibus luculen-

535 ter apparet quid de isto primo articulo sit tenendum. 